\title{
PENGARUH MOTIVASI DAN KOMPETENSI TERHADAP KINERJA PEGAWAI PADA SEKRETARIAT JENDERAL DEWAN PERWAKILAN DAERAH REPUBLIK INDONESIA
}

\author{
N. Lilis Suryani, S.E., M.M. \\ Dosen Fakultas Ekomomi Universitas Pamulang \\ Email : dosen00437@unpam.ac.id
}

\begin{abstract}
ABSTRAK
Secara khusus penelitian ini bertujuan untuk mengetahui seberapa besar pengaruh motivasi (X1) terhadap kinerja (Y) di Sekretariat Jendral Dewan Perwakilan Rakyat Republik Indonesia, untuk mengetahui seberapa besar pengaruh kompetensi (X2) terhadap kinerja (Y) di Sekretariat Jendral Dewan Perwakilan Rakyat Republik Indonesia dan untuk mengetahui seberapa besar pengaruh motivasi (X1) dan kompetensi (X2) terhadap kinerja (Y) di Sekretariat Jendral Dewan Perwakilan Rakyat Republik Indonesia secara simultan

Metode penelitian menggunakan penelitian deskriptif dengan teknik survey. Pendekatan analisis yang dipakai dalam penelitian ini adalah menggunakan pendekatan kuantitatif, jenis statistik yang dipakai dalam penelitian adalah statistik nonparametrik. Sampel penelitian berjumlah 100 responden.

Faktor motivasi dan kompetensi bersama-sama mepunyai pengaruh yang positif dan signifikan terhadap kinerja karyawanSekretariat Jendral Dewan Perwakilan Daerah Republik Indonesia, dari tabel dapat dilihat bahwa R Square diperoleh sebesar 0,750 atau $75 \%$, hal ini dapat dijelaskan bahwa varibel motivasi dan kompetensi secara bersama-sama berpengaruh terhadap kinerja karyawanSekretariat Jendral Dewan Perwakilan Daerah Republik Indonesia dan sisanya $25 \%$ dipengaruhi oleh faktor lain yang tidak diteliti oleh peneliti seperti Intensif pegawai dan lain sebagainya. Dan sesuai dengan rumusan masalah maka besarnya pengaruh motivasi dan kompetensi terhadap kinerja secara simultan yiatu sebesar $75 \%$. model regresi berganda yang diperoleh : Y= $\mathbf{0 , 5 8 7}+\mathbf{0 , 4 7 7} \mathrm{X}_{\mathbf{1}}+\mathbf{0 , 5 4 6} \mathrm{X}_{2}$ dari data-data tersebut didapat bahwa faktor kompetensi yang mempunyai kontribusi yang paling besar pengaruhnya terhadap kinerja karyawanSekretariat Jendral Dewan Perwakilan Daerah Republik Indonesia, jika faktor motivasi konstan, maka kenaikan sebesar satu-satuan pada kompetensi menghasilkan kenaikan kinerja sebesar 0,546 satuan.
\end{abstract}

Kata kunci : Motivasi, Kompetensi, Kinerja 


\section{PENDAHULUAN \\ Latar Belakang}

Sekretariat Jenderal DPD sebagai "suporting system" senantiasa berupaya untuk memberikan dukungan teknis administratif dan keahlian secara optimal kepada DPD RI. Gambaran keadaan masa depan yang diinginkan Sekretariat Jeneral DPD adalah terwujudnya sebuah pelayanan prima kepada DPD, sehingga DPD dapat menjalankan tugas dan wewenangnya dengan baik. Kondisi yang demikian dapat dicapai apabila sumberdaya manusia aparatur Sekretariat Jenderal DPD profesional, netral, akuntabel, sejahtera, dan modern. Dalamrangka mewujudkan keadaan masa depan yang diinginkan itulah, maka Sekretariat JenderalDPD mempunyai Visi, yaitu : "Terciptanya sistem pendukung yang optimal untuk fungsi politik DPD RI pada 2009". (Draft) Visi Sekretariat Jenderal DPD akan dapat terwujud apabila disertai dengan misi untuk mewujudkannya.

Motivasi untuk melakukan litbang dengan mengembangkan inisiatif, inovasi dan kreatifitas dari personil maupun kelompok kerja (pokja) relatif masih rendah. Kalaupun pekerjaan/program kerja litbang itu selesai hanya sebagai sebuah pemenuhan kewajiban administrasi, kurang menyentuh kualitas hasil litbang seperti yang diharapkan. Pegawai yang memiliki motivasi kerja yang tinggi umumnya lebih berhasil dalam tugas dan perkembangan kariernya dibandingkan pegawai yang kurang motivasi. Alasan tersebut diatas mendorong dan menginspirasi penulis untuk melakukan penelitian ini dengan memfokuskan pada "Pengaruh Motivasi dan Kompetensi Terhadap Kinerja Pegawai Pada Sekretariat Jendral Dewan Perwakilan Daerah Republik Indonesia".

\section{Batasan Masalah}

Permasalahan yang menarik untuk dikaji adalah bagaimana menentukan orang yang tepat untuk mengisi suatu jabatan jika jabatan tersebut tidak dibuat dalam suatu batasan yang jelas yang menyangkut ruang lingkup jabatan dan spesifikasi si pemegang jabatan.

Motivasi berasal dari kata Latin movere yang berarti dorongan atau menggerakkan. Motivasi dalam manajemen hanya ditujukan pada sumber daya manusia umumnya dan bawahan khususnya. Motivasi mempersoalkan bagaimana caranya mengarahkan daya dan potensi bawahan agar mau bekerja sama secara produktif berhasil mencapai dan mewujudkan tujuan yang ditentukan (Hasibuan, 2005:141).

Menurut R. Palan (2007:5), Istilah 'competencies, 'competence' dan 'competent' yang dalam bahasa Indonesia diterjemahkan sebagai kompetensi, kecakapandan keberdayaan merujuk pada keadaan atau kualitas mampu dan sesuai. Kamus bahasa Inggris menjelaskan kata 'competence' sebagai keadaan yang sesuai, memadai, atau cocok. Definisi kompetensi di tempat kerja merujuk pada pengertian kecocokan seseorang dengan pekerjaannya. Namun dalam konteks pekerjaan, kompetensi memiliki dua makna yang berbeda, tergantung kerangka referensi organisasinya.

Stephen P. Robbins (2001:6) menyebutkan bahwa secara sederhana kinerja karyawan adalah fungsi dari interaksi antara kemampuan (ability) dan motivasi (motivation), tetapi masih ada bagian yang masih hilang dari fungsi tersebut selain kecerdasan dan keahlian dari seorang individu yang keduanya merupakan bagian dari kemampuan dan motivasi dari setiap karyawan, yaitu kesempatan.

Penelitian dilaksanakan di Sekretariat Jendral Dewan Perwakilan Daerah Republik Indonesia mulai tanggal 1 Maret 2014 sampai dengan 30 November 2014.

\section{Identifikasi Masalah}

Berdasarkan latar belakang penelitian, maka dapat diidentifikasi masalahnya yaitu: 
1. Menurunnya kinerja pegawai pada Sekretariat Jendral Dewan Perwakilan Daerah Republik Indonesia.

2. Banyak pegawai pada Sekretariat Jendral Dewan Perwakilan Daerah Republik Indonesia memiliki motivasi kerja yang rendah sehingga setiap tugas yang diberikan pimpinan cenderung tidak menghasilkan hasil kerja yang memuaskan.

3. Motivasi kerja pegawai pada Sekretariat Jendral Dewan Perwakilan Daerah Republik Indonesia. masih kurang memenuhi harapan (relatif rendah).

4. Kebijakan-kebijakan yang tidak konsisten dari pimpinan di Sekretariat Jendral Dewan Perwakilan Daerah Republik Indonesia. menyebabkan terjadinya kegamangan pegawai dan miskomunikasi dalam pelaksanaan tugas.

5. Penempatan pegawai yang kurang sesuai dengan kemampuan dan latar belakang pendidikan menyebabkan para pegawai tidak mampu menunjukkan kinerja dengan baik.

6. Kinerja pegawai pada Sekretariat Jendral Dewan Perwakilan Daerah Republik Indonesia masih rendah karena kurangnya motivasi dan kompetensi

\section{Rumusan Masalah}

Adapun rumusan masalahnya adalah: Seberapa besar pengaruh motivasi (X1) terhadap kinerja (Y) di Sekretariat Jendral Dewan Perwakilan Rakyat Republik Indonesia?

1. Seberapa besar pengaruh kompetensi (X2) terhadap kinerja (Y) di Sekretariat Jendral Dewan Perwakilan Rakyat Republik Indonesia?

2. Seberapa besar pengaruh motivasi (X1) dan kompetensi (X2) terhadap kinerja (Y) di Sekretariat Jendral Dewan Perwakilan Rakyat Republik Indonesia secara simultan?

\section{Tujuan Penelitian}

Berdasarkan perumusan masalah diatas, maka tujuan yang hendak dicapai dari penelitian ini adalah memperoleh data dan informasi yang tepat untuk menganalisis data. Secara khusus penelitian ini bertujuan untuk:

1. Untuk mengetahui seberapa besar pengaruh motivasi (X1) terhadap kinerja (Y) di Sekretariat Jendral Dewan Perwakilan Rakyat Republik Indonesia

2. Untuk mengetahui seberapa besar pengaruh kompetensi (X2) terhadap kinerja (Y) di Sekretariat Jendral Dewan Perwakilan Rakyat Republik Indonesia

3. Untuk mengetahui seberapa besar pengaruh motivasi (X1) dan kompetensi (X2) terhadap kinerja (Y) di Sekretariat Jendral Dewan Perwakilan Rakyat Republik Indonesia secara simultan

\section{Kerangka Pemikiran}

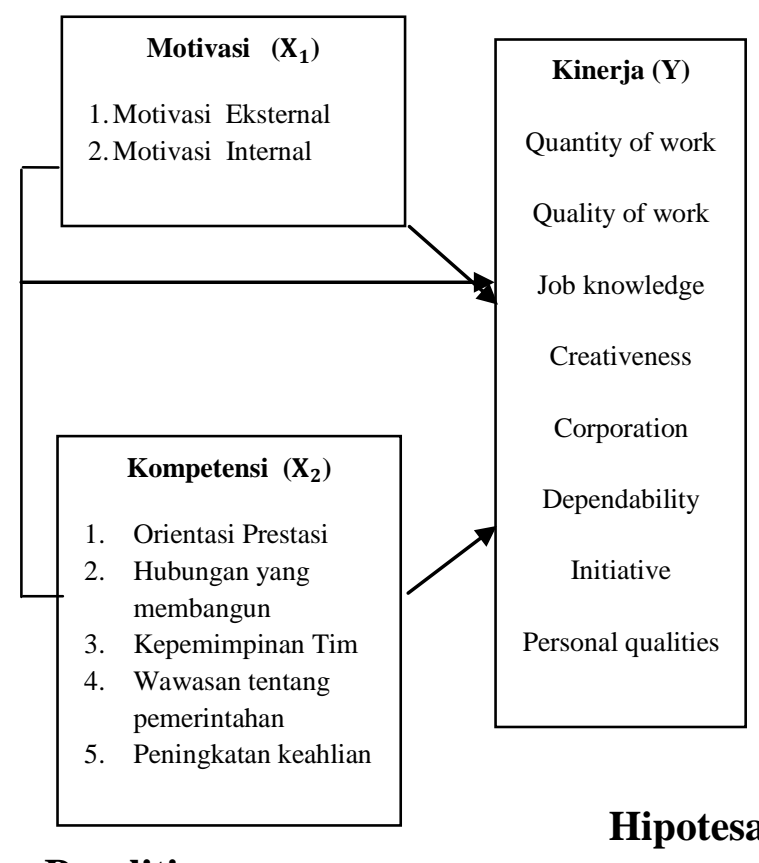

\section{Penelitian}

Berdasarkan kerangka pemikiran diatas, maka dapat diajukan suatu hipotesa penelitian, yaitu:

1. Diduga motivasi (X1) berpengaruh positif dan signifikan terhadap kinerja (Y) di Sekretariat Jendral Dewan Perwakilan Daerah Republik Indonesia

2. Diduga kompetensi (X2) berpengaruh positif dan signifikan terhadap kinerja (Y) di Sekretariat Jendral Dewan Perwakilan Daerah Republik Indonesia 
3. Diduga motivasi (X1) dan kompetensi (X2) berpengaruh positif dan signifikan terhadap kinerja (Y) di Sekretariat Jendral Dewan Perwakilan Daerah Republik Indonesia

\section{LANDASAN TEORI Motivasi}

Menurut (Hasibuan, 2005:141), Motivasi berasal dari kata Latin movere yang berarti dorongan atau menggerakkan. Motivasi dalam manajemen hanya ditujukan pada sumber daya manusia umumnya dan bawahan khususnya. Motivasi mempersoalkan bagaimana caranya mengarahkan daya dan potensi bawahan agar mau bekerja sama secara produktif berhasil mencapai dan mewujudkan tujuan yang ditentukan.

Pentingnya Motivasi karena Motivasi adalah hal yang menyebabkan, menyalurkan, dan mendukung perilaku manusia, supaya mau bekerja giat dan antusias mencapai hasil yang maksimal. Motivasi semakin penting karena manajer membagikan pekerjaan pada bawahannya untuk dikerjakan dengan baik dan terintegrasi dengan baik kepada tujuan yang diinginkan.

\section{Kompetensi}

Menurut R. Palan (2007:5), Istilah 'competencies, 'competence' dan 'competent' yang dalam bahasa Indonesia diterjemahkan sebagai kompetensi, kecakapandan keberdayaan merujuk pada keadaan atau kualitas mampu dan sesuai. Kamus bahasa Inggris menjelaskan kata 'competence' sebagai keadaan yang sesuai, memadai, atau cocok. Definisi kompetensi di tempat kerja merujuk pada pengertian kecocokan seseorang dengan pekerjaannya. Namun dalam konteks pekerjaan, kompetensi memiliki dua makna yang berbeda, tergantung kerangka referensi organisasinya.

Kompetensi merujuk kepada karakteristik yang mendasari perilaku yang menggambarkan motif, karakteristik pribadi (ciri khas), konsep diri, nilai-nilai, pengetahuan atau keahlian yang dibawa seseorang yang berkinerja unggul (superior performer) di tempat kerja.

Kinerja

Kinerja adalah hasil kerja yang dapat dicapai oleh seseorang atau sekelompok orang dalam suatu organisasi, sesuai dengan wewenang dan tanggungjawab masing-masing, dalam rangka upaya mencapai tujuan organisasi bersangkutan secara legal, tidak melanggar hukum dan sesuai dengan moral dan etika, Prawirosentono dalam Sinambela (2012:5). Rumusan di atas menjelaskan bahwa kinerja adalah tingkat keberhasilan seseorang atas lembaga dalam melaksanakan pekerjaannya. Dari definisi di atas, terdapat setidaknya empat elemen yaitu: (1) hasil kerja yang dicapai secara individual atau secara instansi, yang berarti bahwa kinerja tersebut adalah "hasil akhir" yang diperoleh secara sendiri - sendiri atau berkelompok (2) dalam melaksanakan tugas, orang atau lembaga diberikan wewenang Kinerja Pegawai; Teori, Pengukuran dan Implikasi dan tanggung jawab, yang berarti orang atau lembaga diberikan hak dan kekuasaan untuk bertindak dak sehingga pekerjaannya dapat dilakukan dengan baik meskipun demikian orang atau lembaga tersebut tetap harus dalam kendali, yakni mempertanggungjawabkan pekerjaannya kepada pemberi hak dan wewenang, sehingga dia tidak akan menyalahgunakan hak dan wewenangnya tersebut. (3) Pekerjaan haruslah dilakukan secara legal, yang berarti dalam melaksanakan tugastugas individu atau lembaga tentu saja harus mengikuti aturan yang telah ditetapkan, dan (4)Pekerjaan tidaklah bertentangan dengan moral aim, etika, artinya selain mengikuti aturan yang telah ditetapkan, tentu saja pekerjaan tersebut haruskah sesuai dengan moral dan etika yang berlaku umum.

\section{METODOLOGI PENELITIAN}

\section{A. Tempat dan Waktu Penelitian}

Penelitian dilaksanakan di Sekretariat Jenderal Dewan Perwakilan Daerah Republik Indonesia yang berlokasi di Jalan Jendral Gatot Subroto no. 6, 
Senayan. Jakarta Pusat. .

\section{B. Metode Penelitian}

Penelitian yang dilakukan penulis di Sekretariat Jenderal Dewan Perwakilan Daerah Republik Indonesia, dilakukan dengan menggunakan metode Deskriptif dengan teknik survey, yang dalam hal ini pengertian deskriptif menurut Winarno Surakhmad ( 2005 : 139 ) bahwa :

'Penyelidikan deskriptif tertuju pada pemecahan masalah yang ada pada masa sekarang. Karena banyak sekali ragam penyelidikan demikian, metode penyelidikan deskriptif lebih merupakan istilah umum yang mencakup berbagai teknik deskriptif, diantaranya ialah penyelidikan yang menuturkan, menganalisa, dan mengklasifikasikan penyelidikan dengan teknik survey, interview, angket, observasi, atau teknik test'.

Berdasarkan pengertian tersebut, penelitian yang dilakukan penulis dengan cara melihat langsung kegiatan yang dilakukan pada obyek penelitian, mencatat, menganalisis, menyimpulkan, serta menggunakannya sebagai bahan penyusunan tesis ini.

Pendekatan analisis yang dipakai dalam penelitian ini adalah menggunakan pendekatan kuantitatif, jenis statistik yang dipakai dalam penelitian adalah statistik non parametrik. Menurut Sugiyono (2007:224):

"Statistik non parametrik digunakan untuk menguji hipotesis bila datanya berbentuk nominal atau ordinal, dan tidak berlandaskan asumsi bahwa distribusi data harus normal"“.

Peneliti menggunakan statistik nonparametrik karena data yang diolah berbentuk ordinal.

\section{Desain Penelitian}

Desain yang digunakan dalam penelitian ini bersifat deskriptif kuantitatif dengan tujuan mengetahui seberapa besar pengaruh Motivasi dan Kompetensi Terhadap Kinerja Karyawan di Sekretariat
Jenderal Dewan Perwakilan Daerah Republik Indonesia

Tahapan penelitian dilakukan melalui beberapa tahapan, yakni menentukan fokus penelitan, lokasi penelitian, mengumpulkan data-data dan mencari sumber-sumber data sesuai dengan kebutuhan penelitian, menentukan jumlah populasi/sampel yang akan dicari sebagai responden, menguraikan variabel-variabel penelitian, menyusun instrumen, selanjutnya dilakukan pengumpulan data dan kuesioner.

Selanjutnya tahapan menganalisis data yang sudah terkumpul. Tahap terakhir merupakan kesimpulan dan saran serta rekomendasi.

\section{Defisiensi Operasional Variabel}

Secara operasional variabel perlu didefinisikan yang bertujuan untuk menjelaskan makna variabel penelitian.

Singarimbun dalam Riduwan (2009 : 281) memberikan pengertian tentang definisi operasional adalah unsur penelitian yang memberikan petunjuk bagaimana variabel itu diukur. Definisi operasional variable tersebut adalah :

1. Menurut (Hasibuan, 2005:141), Motivasi berasal dari kata Latin movere yang berarti dorongan atau menggerakkan. Motivasi dalam manajemen hanya ditujukan pada sumber daya manusia umumnya dan bawahan khususnya. Motivasi mempersoalkan bagaimana caranya mengarahkan daya dan potensi bawahan agar mau bekerja sama secara produktif berhasil mencapai dan mewujudkan tujuan yang ditentukan.

2. Kompetensi terdiri dari beberapa jenis karakteristik yang berbeda, yang mendorong perilaku. Fondasi karakteristik ini terbukti dalam cara seseorang berperilaku di tempat kerja. Kompetensi adalah mengenai orang seperti apa dan apa yang dapat mereka lakukan, bukan apa yang mungkin mereka lakukan. 
Kompetensi ditemukan pada orangorang yang diklasifikasikan sebagai berkinerja unggul atau efektif. Yang dimaksud kinerja unggul adalah kinerja di atas rata-rata. Biasanya mereka adalah sepuluh persen karyawan terbaik. Sebagai contoh, seorang wiraniaga yang berorientasi prestasimenetapkan sasaran yang sangat menantang, dan berhasil mencapainya. Hasil yang dicapainya tersebutmemberi keuntungan bagi wiraniaga tersebut maupun organisasi. Sebuah contoh lain, kompetensi hubungan antarpribadi (interpersonal) ditunjukkan melalui seberapa efektif seseorang bergaul dengan karyawan (anggota tim) lain di tempat kerja.

3. Konsep kompetensi berawal dari artikel David Mc. Clelland yang menggegerkan, Testing for Competence Rather than intelligence. Artikel tersebut meluncurkan gerakan kompetensi dalam psikologi industrial. Dia menyimpulkan, berdasarkan kajian hasil penelitian, bahwa tes kecakapan akademis tradisional dan tes pengetahuan isi, serta nilai dan ijazah sekolah:

1. Tidak dapat memprediksi keberhasilan di pekerjaan/kehidupan.

2. Biasanya bias terhadap masyarakat yang sosial ekonomi rendah.

Karakteristik-karakteristik atau kompetensi-kompetensi ini, ketika muncul dan dipertunjukkan secara konsisten, mengarah pada kesuksesan hasil kerja.

4. Kinerja merupakan hasil pencapaian kerja secara kualitas dan kuantitas yang dicapai oleh seorang pegawai dalam melaksanakan tugasnya sesuai dengan tanggung jawab yang diberikan kepadanya (Mangkunegara, 2008 : 67). Untuk variabel terikat yaitu kinerja, digunakan variabel indikator yang antara lain :
a. Hasil Kerja
b. Perilaku Kerja
c. Sifat Pribadi

Selanjutnya, variabel-variabel indikator inilah yang kemudian dikembangkan oleh penulis menjadi instrumen penelitian yang dalam hal ini adalah pertanyaan-pertanyaan di dalam kuisioner penelitian.

Tabel 7.

Kisi-kisi Opresional Variabel Penelitian

\begin{tabular}{|c|c|c|c|}
\hline Variabel & $\begin{array}{c}\text { Dimensi/Indik } \\
\text { ator }\end{array}$ & $\begin{array}{c}\text { Ukur } \\
\text { an }\end{array}$ & $\begin{array}{c}\text { But } \\
\text { ir } \\
\text { Soa } \\
1\end{array}$ \\
\hline $\begin{array}{l}\text { Motivasi } \\
\text { (X1) }\end{array}$ & $\begin{array}{l}\text { Motivasi } \\
\text { Eksternal }\end{array}$ & $\begin{array}{c}\text { Ordin } \\
\text { al }\end{array}$ & $\begin{array}{l}\text { No. } \\
1 \\
\text { s/d } \\
6\end{array}$ \\
\hline & $\begin{array}{l}\text { Motivasi } \\
\text { Internal }\end{array}$ & $\begin{array}{l}\text { Ordin } \\
\text { al }\end{array}$ & $\begin{array}{l}\text { No. } \\
7 \\
\text { s/d } \\
12\end{array}$ \\
\hline \multirow{5}{*}{$\begin{array}{c}\text { Kompete } \\
\text { nsi } \\
\text { (X2) }\end{array}$} & $\begin{array}{l}\text { Orientasi } \\
\text { Prestasi }\end{array}$ & $\begin{array}{l}\text { Ordin } \\
\text { al }\end{array}$ & $\begin{array}{l}\text { No. } \\
13 \\
\text { s/d } \\
15\end{array}$ \\
\hline & $\begin{array}{l}\text { Hubungan } \\
\text { yang } \\
\text { membangun }\end{array}$ & $\begin{array}{l}\text { Ordin } \\
\text { al }\end{array}$ & $\begin{array}{l}\text { No. } \\
16 \\
\text { s/d } \\
18\end{array}$ \\
\hline & $\begin{array}{l}\text { Kepemimpinan } \\
\text { Tim }\end{array}$ & $\begin{array}{l}\text { Ordin } \\
\text { al }\end{array}$ & $\begin{array}{l}\text { No. } \\
19 \\
\text { dan } \\
20\end{array}$ \\
\hline & $\begin{array}{l}\text { Wawasan } \\
\text { tentang } \\
\text { pemerintahan }\end{array}$ & $\begin{array}{l}\text { Ordin } \\
\text { al }\end{array}$ & $\begin{array}{l}\text { No. } \\
21 \\
\text { dan } \\
22\end{array}$ \\
\hline & $\begin{array}{l}\text { Peningkatan } \\
\text { keahlian }\end{array}$ & $\begin{array}{l}\text { Ordin } \\
\text { al }\end{array}$ & $\begin{array}{l}\text { No. } \\
23 \\
\text { dan } \\
24\end{array}$ \\
\hline
\end{tabular}




\begin{tabular}{|c|c|c|c|}
\hline \multirow{6}{*}{$\begin{array}{c}\text { Kinerja } \\
\text { Karyawa } \\
\text { n } \\
(\mathbf{Y})\end{array}$} & Kualitas kerja & $\begin{array}{l}\text { Ordin } \\
\text { al }\end{array}$ & $\begin{array}{l}\text { No. } \\
25 \\
\text { dan } \\
26\end{array}$ \\
\hline & $\begin{array}{l}\text { Kuantitas } \\
\text { Kerja }\end{array}$ & $\begin{array}{l}\text { Ordin } \\
\text { al }\end{array}$ & $\begin{array}{l}\text { No. } \\
27 \\
\text { dan } \\
28\end{array}$ \\
\hline & Pengetahuan & $\begin{array}{c}\text { Ordin } \\
\text { al }\end{array}$ & $\begin{array}{l}\text { No. } \\
29 \\
\text { dan } \\
30\end{array}$ \\
\hline & $\begin{array}{l}\text { Penyesuaian } \\
\text { pekerjaan }\end{array}$ & $\begin{array}{l}\text { Ordin } \\
\text { al }\end{array}$ & $\begin{array}{l}\text { No. } \\
31 \\
\text { dan } \\
32\end{array}$ \\
\hline & Keandalan & $\begin{array}{c}\text { Ordin } \\
\text { al }\end{array}$ & $\begin{array}{l}\text { No. } \\
33 \\
\text { dan } \\
34\end{array}$ \\
\hline & $\begin{array}{l}\text { Keselamatan } \\
\text { kerja }\end{array}$ & $\begin{array}{l}\text { Ordin } \\
\text { al }\end{array}$ & $\begin{array}{l}\text { No. } \\
35 \\
\text { dan } \\
36\end{array}$ \\
\hline
\end{tabular}

\section{E. Sumber dan Cara Pengumpulan data/Informasi}

\section{Sumber Data}

Sumber data yang digunakan dalam penelitian ini terdiri dari dua macam yaitu data primer dan data sekunder.

1. Data Primer

Data primer adalah data yang diperoleh penulis melalui observasi atau pengamatan langsung dari lembaga, baik itu melalui observasi, kuesioner dan wawancara secara langsung dengan pegawai lembaga sesuai dengan kebutuhan dalam penelitian ini.

2. Data Sekunder

Data sekunder merupakan data yang diperoleh tidak langsung, yaitu data tersebut diperoleh penulis dari dokumen-dokumen lembaga dan buku-buku literatur yang memberikan informasi tentang proses Motivasi dan Kompetensi Terhadap Kinerja Karyawan di Sekretariat Jendral Dewan Perwakilan Daerah Republik Indonesia.

\section{Cara}

\section{Data/Informasi}

\section{Pengumpulan}

Proses pengumpulan data yang diperlukan dalam pembahasan ini melalui dua tahap penelitian, yaitu:

1. Studi Kepustakaan (Library Research)

Studi kepustakaan digunakan untuk mengumpulkan data sekunder dari lembaga, landasan teori dan informasi yang berkaitan dengan penelitian ini dengan cara dokumentasi. Studi dilakukan antara lain dengan mengumpulkan data yang bersumber dari literaturliteratur, bahan kuliah, dan hasil penelitian lainnya yang ada hubungannya dengan objek penelitian. Hal ini dilakukan untuk mendapatkan tambahan pengetahuan mengenai masalah yang sedang dibahas.

2. Studi Lapangan (Field Research)

Dalam penelitian ini penulis mengumpulkan data yang diperlukan dengan cara melakukan pengamatan langsung pada lembaga baik melalui observasi, penyebaran kuesioner kepada para pegawai, dan wawancara.

Penelitian Lapangan dilakukan dengan cara :

a. Wawancara adalah metode untuk mendapatkan data dengan cara melakukan tanya jawab secara langsung dengan pihak- 
pihak yang bersangkutan guna mendapatkan data dan keterangan yang menunjang analisis dalam penelitian.

b. Observasi adalah teknik pengumpulan data dengan cara melakukan pengamatan langsung pada obyek yang diteliti sehingga diperoleh gambaran yang jelas mengenai masalah yang dihadapi oleh pegawai.

c. Kuesioner, adalah pengumpulan data dengan cara menyebarkan daftar pertanyaan kepada responden yang dijadikan sebagai sampel penelitian.

\section{F. Teknik Penentuan Data}

Pada penelitian ini, penulis menjadikan pegawai sekretariat Jendral Dewan Perwakilan Daerah Republik Indonesia sebagai populasi, yang sampai tahun 2014 totalnya berjumlah 464 orang.

Kemudian akan digunakan metode Simple Random Sampling, yaitu metode penarikan sampel dimana setiap anggota populasi mempunyai peluang yang sama untuk dipilih menjadi sampel. Adapun jumlah sampel tersebut diperoleh dari perhitungan yang dikemukakan oleh Slovin dalam Husain (2003 : 146) sebagai berikut :

Dimana : $\mathrm{n}=\frac{N}{1+N e^{2}}$

$\mathrm{n} \quad=$ Ukuran sampel

$\mathrm{N}=$ Ukuran populasi yaitu pegawai

$\mathrm{e}=$ Persen kelonggaran

ketidaktelitian karena kesalahan pengambilan sampel yang masih dapat dirolerir atau diinginkan, sebanyak $10 \%$.

Berdasarkan rumus tersebut, maka jumlah sampel yang diambil dalam penelitian ini adalah:

$$
\begin{array}{r}
n=\frac{464}{1+464(10 \%)^{2}} \\
n=99,78
\end{array}
$$

Dengan demikian, jumlah sampel yang digunakan sebagai responden dalam penelitian ini sebanyak 100 orang karyawan.

\section{G. Rancangan Analisis dan Uji Hipotesis \\ 1. Rancangan Analisis}

Untuk membuktikan hipotesis yang telah dikemukakan maka dalam penelitian ini digunakan :

\section{Analisis Deskriptif Kuantitatif}

Merupakan metode yang bertujuan mengubah kumpulan data mentah menjadi bentuk yang mudah dipahami, dalam bentuk informasi yang ringkas, dimana hasil penelitian beserta analisanya diuraikan dalam suatu tulisan ilmiah yang mana dari analisis tersebut akan dibentuk suatu kesimpulan.

\section{Analisis Regresi Berganda}

Untuk mengetahui hubungan dan pengaruh antara proses rekrutmen dan seleksi dengan kinerja karyawan digunakan teknik analisis regresi berganda, untuk mengetahui besarnya pengaruh secara kuantitatif (variabel X) terhadap (variabel $\mathrm{Y}$ ). Analisis regresi menggunakan rumus persamaan regresi berganda seperti

yang dikutip dalam Sugiyono (2009 : 277), yaitu :

Dimana :

$$
\mathrm{Y}=\mathrm{a}+\mathrm{b} 1 \mathrm{X} 1+\mathrm{b} 2 \mathrm{X} 2
$$

Y = Variabel dependen, yaitu Kinerja karyawan

$\mathrm{X} 1$ = Variabel independen, yaitu Proses Rekrutmen

$\mathrm{X} 2$ = Variabel independen, yaitu Proses pelatihan

$\mathrm{a}=$ Konstanta yang merupakan ratarata nilai $\mathrm{Y}$ pada saat nilai $\mathrm{X} 1$ dan $\mathrm{X} 2$ sama dengan nol 
b1 =Koefisien regresi parsial, mengukur rata-rata nilaiYuntuk tiap perubahan X1 dengan menganggap $\mathrm{X} 2$ konstan.

b2 $=$ Koefisien regresi parsial, mengukur rata-rata nilai $Y$ untuk tiap perubahan $\mathrm{X} 2$

dengan menganggap X1 konstan.

\section{Analisis Koefisien Determinasi (R2)}

Pada model linear berganda ini, akan dilihat besarnya kontribusi untuk variabel bebas secara bersama-sama terhadap variabel terikatnya dengan melihat besarnya koefisien determinasi totalnya (R2). Jika (R2) yang diperoleh mendekati 1 (satu) maka dapat dikatakan semakin kuat model tersebut menerangkan hubungan variabel bebas terhadap variabel terikat. Sebaliknya jika (R2) makin mendekati 0 (nol) maka semakin lemah pengaruh variabel-variabel bebas terhadap variabel terikat.

\section{Uji Hipotesis (Uji F dan T)}

Uji ini digunakan untuk mengetahui pengaruh bersama-sama variabel bebas terhadap varibel terikat. Dimana $\mathrm{F}$ hitung $>$ Ftabel, maka $\mathrm{H}_{1}$ diterima atau secara bersama-sama variabel bebas dapat menerangkan variabel terikatnya secara serentak. Sebaliknya apabila Fhitung < Ftabel, maka Ho diterima atau secara bersamasama variabel bebas tidak memiliki pengaruh terhadap variabel terikat. Untuk mengetahui signifikan atau tidak pengaruh secara bersama-sama variabel bebas terhadap variabel terikat maka digunakan probability sebesar 5\% $(\alpha=$ 0,05).Jika sig $>\alpha ́(0,05)$, maka Ho diterima $\mathrm{H}_{1}$ ditolak.Jika sig < $\alpha(0,05)$, maka Ho ditolak $\mathrm{H}_{1}$ diterima.

Sedangkan Uji T digunakan untuk mengetahui apakah masing-masing variabel bebasnya secara sendiri-sendiri berpengaruhsecara signifikan terhadap variabel terikatnya. Dimana Ttabel > Thitung, Ho diterima.
Dan jika Ttabel < Thitung, maka $\mathrm{H}_{1}$ diterima, begitupun jika sig $>\alpha$. $(0,05)$, maka Ho diterima $\mathrm{H}_{1}$ ditolak dan jika sig < $\alpha(0,05)$, maka Ho ditolak, $\mathrm{H}_{1}$ diterima.

\section{HASIL PENELITIAN}

\section{A. Gambaran Umum Obyek Penelitian}

Dewan Perwakilan Daerah

Republik Indonesia (DPD RI) lahir pada tanggal 1 Oktober 2004, ketika 128 anggota DPD yang terpilih untuk pertama kalinya dilantik dan diambil sumpahnya.

Pada awal pembentukannya, masih banyak tantangan yang dihadapi oleh DPD RI. Tantangan tersebut mulai dari wewenangnya yang dianggap jauh dari memadai untuk menjadi kamar kedua yang efektif dalam sebuah parlemen bikameral, sampai dengan persoalan kelembagaannya yang juga jauh dari memadai. Tantangan-tantangan tersebut timbul terutama karena tidak banyak dukungan politik yang diberikan kepada lembaga baru ini.

\section{B. Deskripsi Data}

\section{1.) Uji Validitas}

Untuk mengelola uji validitas penulis menggunakan perhitungan statistic dengan software SPSS (Statistical Program For Social Science) version 17.00 for windows diperoleh $\mathrm{r}$ hitung lebih besar dari $\mathrm{r}$ table dan nilai $r$ positif, maka butir pernyataan dikatakan valid, jika nilai $r$ hitung > r tabel, sesuai dengan pernyataan Sugiyono (2013:182-183) yaitu nilai $r$ tabel sebesar 0,3 dimana $r$ hitung $>0,3$ "Valid" dan $r$ hitung $<0,3$

" Tidak Valid".

\section{a. Uji Validitas Variabel Motivasi}

\section{Tabel 8}

Uji Validitas Variabel Motivasi

\begin{tabular}{|c|c|c|c|c|}
\hline No & Pertanyaan & r- hitung & r- tabel & Keterangan \\
\hline 1 & $\begin{array}{c}\text { Kuesioner } \\
1\end{array}$ & 0.673 & 0.3 & Valid \\
\hline
\end{tabular}




\begin{tabular}{|c|c|c|c|c|}
2 & $\begin{array}{c}\text { Kuesioner } \\
2\end{array}$ & 0.564 & 0.3 & Valid \\
\hline 3 & $\begin{array}{c}\text { Kuesioner } \\
3\end{array}$ & 0.755 & 0.3 & Valid \\
\hline 4 & $\begin{array}{c}\text { Kuesioner } \\
4\end{array}$ & 0.536 & 0.3 & Valid \\
\hline 5 & $\begin{array}{c}\text { Kuesioner } \\
5\end{array}$ & 0.496 & 0.3 & Valid \\
\hline 6 & $\begin{array}{c}\text { Kuesioner } \\
6\end{array}$ & 0.604 & 0.3 & Valid \\
\hline 7 & $\begin{array}{c}\text { Kuesioner } \\
7\end{array}$ & 0.717 & 0.3 & Valid \\
\hline 8 & $\begin{array}{c}\text { Kuesioner } \\
8\end{array}$ & 0.425 & 0.3 & Valid \\
\hline 9 & $\begin{array}{c}\text { Kuesioner } \\
9\end{array}$ & 0.540 & 0.3 & Valid \\
\hline 10 & $\begin{array}{c}\text { Kuesioner } \\
10\end{array}$ & 0.519 & 0.3 & Valid \\
\hline 11 & $\begin{array}{c}\text { Kuesioner } \\
11\end{array}$ & 0.564 & 0.3 & Valid \\
\hline 12 & $\begin{array}{c}\text { Kuesioner } \\
12\end{array}$ & 0.755 & 0.3 & Valid \\
\hline
\end{tabular}

Sumber: data premier yang sudah diolah 2015

Berdasarkan hasil uji validitas yang telah dilakukan terhadap variabel motivasi maka nilai $\mathrm{r}$ hitung memiliki nilai lebih besar dari nilai $r$ tabel yaitu 0,3 sehingga dinyatakan valid.

b. Uji Validitas Variabel Kompetensi

Tabel 9

Uji Validitas Variabel Kompetensi

\begin{tabular}{|c|c|c|c|c|}
\hline No & Pertanyaan & $\mathrm{r}_{\text {- } \text { hitung }}$ & $\mathrm{r}^{-}$tabel & Keterangan \\
\hline 1 & $\begin{array}{c}\text { Kuesioner } \\
1\end{array}$ & 0.523 & 0.3 & Valid \\
\hline 2 & $\begin{array}{c}\text { Kuesioner } \\
2\end{array}$ & 0.475 & 0.3 & Valid \\
\hline 3 & $\begin{array}{c}\text { Kuesioner } \\
3\end{array}$ & 0.485 & 0.3 & Valid \\
\hline 4 & $\begin{array}{c}\text { Kuesioner } \\
4\end{array}$ & 0.570 & 0.3 & Valid \\
\hline 5 & $\begin{array}{c}\text { Kuesioner } \\
5\end{array}$ & 0.462 & 0.3 & Valid \\
\hline 6 & $\begin{array}{c}\text { Kuesioner } \\
6\end{array}$ & 0.392 & 0.3 & Valid \\
\hline 7 & $\begin{array}{c}\text { Kuesioner } \\
7\end{array}$ & 0.661 & 0.3 & Valid \\
\hline 8 & $\begin{array}{c}\text { Kuesioner } \\
8\end{array}$ & 0.608 & 0.3 & Valid \\
\hline 9 & $\begin{array}{c}\text { Kuesioner } \\
9\end{array}$ & 0.639 & 0.3 & Valid \\
\hline 10 & $\begin{array}{c}\text { Kuesioner } \\
10\end{array}$ & 0.636 & 0.3 & Valid \\
\hline 11 & $\begin{array}{c}\text { Kuesioner } \\
11\end{array}$ & 0.600 & 0.3 & Valid \\
\hline 12 & $\begin{array}{c}\text { Kuesioner } \\
12\end{array}$ & 0.536 & 0.3 & Valid \\
\hline
\end{tabular}

Sumber: data premier yang sudah diolah 2015

Jika dilihat dari hasil uji validitas yang telah dilakukan terhadap variabel kompetensi maka nilai $r$ hitung memiliki nilai lebih besar dari nilai $r$ tabel yaitu 0,3 sehingga dinyatakan valid.

c. Uji Validitas Variabel Kinerja

Tabel 10

Uji Validitas Variabel Kinerja Karyawan

\begin{tabular}{|c|c|c|c|c|}
\hline No & Pertanyaan & $\mathrm{r}$ - hitung & r- ${ }_{\text {tabel }}$ & Keterangan \\
\hline 1 & $\begin{array}{c}\text { Kuesioner } \\
1\end{array}$ & 0.705 & 0.3 & Valid \\
\hline 2 & $\begin{array}{c}\text { Kuesioner } \\
2\end{array}$ & 0.748 & 0.3 & Valid \\
\hline 3 & $\begin{array}{c}\text { Kuesioner } \\
3\end{array}$ & 0.544 & 0.3 & Valid \\
\hline 4 & $\begin{array}{c}\text { Kuesioner } \\
4\end{array}$ & 0.438 & 0.3 & Valid \\
\hline 5 & $\begin{array}{c}\text { Kuesioner } \\
5\end{array}$ & 0.666 & 0.3 & Valid \\
\hline 6 & $\begin{array}{c}\text { Kuesioner } \\
6\end{array}$ & 0.583 & 0.3 & Valid \\
\hline 7 & $\begin{array}{c}\text { Kuesioner } \\
7\end{array}$ & 0.462 & 0.3 & Valid \\
\hline 8 & $\begin{array}{c}\text { Kuesioner } \\
8\end{array}$ & 0.625 & 0.3 & Valid \\
\hline 9 & $\begin{array}{c}\text { Kuesioner } \\
9\end{array}$ & 0.654 & 0.3 & Valid \\
\hline 10 & $\begin{array}{c}\text { Kuesioner } \\
10\end{array}$ & 0.619 & 0.3 & Valid \\
\hline 11 & $\begin{array}{c}\text { Kuesioner } \\
11\end{array}$ & 0.567 & 0.3 & Valid \\
\hline 12 & $\begin{array}{c}\text { Kuesioner } \\
12\end{array}$ & 0.483 & 0.3 & Valid \\
\hline
\end{tabular}

Sumber: data premier yang sudah diolah 2015

Jika dilihat uji validitas yang telah dilakukan terhadap variabel kinerja maka nilai $r$ hitung memiliki nilai lebih besar dari nilai $r$ tabel yaitu 0,3 sehingga dinyatakan valid.

\section{2.) Uji Reliabilitas}

Reliabilitas merupakan serangkaian pengukuran atau serangkaian alat ukur yang memiliki konsistensi bila pengukuran yang dilakukan dengan alat ukur itu dilakukan secara berulang, (Sugiyono, 2005).

Untuk mengelola uji reliabilitas digunakan software SPSS (Statistical Program For Social Science) version 17.00 for windows, jika nialai alpha cronbach 
$>\mathrm{r}$ table dan nilai $\mathrm{r}$ positif maka butir pernyataan dikatakan reliable, menurut Sugiyono (2013:184) suatu instrument dikatakna Reliable bila koefisiensi reliabilitas minimal 0,6 sehingga uji reliabelitas dalam penelitian ini dapat dilihat pada tabel berikut ini:

Tabel 11

Uji Reliabelitas Variabel Motivasi, Kompetensi dan Kinerja

\begin{tabular}{|c|c|c|c|}
\hline Variabel & $\begin{array}{c}\text { Alpa } \\
\text { Cronba } \\
\text { ch }\end{array}$ & $\begin{array}{c}\text { Nilai } \mathrm{r} \\
\text { table }\end{array}$ & $\begin{array}{c}\text { Ketera } \\
\text { ngan }\end{array}$ \\
\hline Motivasi & 0.832 & 0.6 & Reliabel \\
\hline Kompetensi & 0.790 & 0.6 & Reliabel \\
\hline Kinerja & 0.829 & 0.6 & Reliabel \\
\hline
\end{tabular}

Sumber: data premier yang sudah diolah 2015

Untuk melihat lebih jelas hasil olahan dengan menggunakan program software SPSS (Statistical Program For Social Science) version 17.00 for windows dapat dilihat pada lampiran.

\section{Analisis Data}

1. Analisis Deskriptif

Analisi deskriptif merupakan bagian dari statistic yang digunakan untuk menggambarkan atau mendeskripsikan data tanpa bermaksud mengeneralisasi atau membuat kesimpulan tapi hanya menjelaskan kelompok data itu saja. Analisi deskripsi dapat meliputi beberapa hal diantarana frekunesi jawaban responden:

a. Penilaian Responden Terhadap Motivasi

Penilaian yang diberikan oleh responden terhadap motivasi merupakan salah satu indicator mengenai motivasi yang ada pada perusahaan dan data peneialain diperoleh berdasarkan hasil kuesioner yang disebarkan kepada 100 responden, mendapat penilaian sebagai berikut:

\section{Tabel 12}

Penilaian RespondenTerhadap Motivasi

\begin{tabular}{|c|c|c|c|c|c|c|c|}
\hline $\begin{array}{c}\text { Dimens } \\
\text { i }\end{array}$ & $\begin{array}{l}\mathbf{N} \\
\mathbf{0} .\end{array}$ & Indikator & SS & $\mathbf{S}$ & CS & $\begin{array}{l}\mathbf{K} \\
\mathbf{S}\end{array}$ & $\begin{array}{l}\mathbf{T} \\
\mathbf{S}\end{array}$ \\
\hline \multirow{6}{*}{$\begin{array}{c}\text { Motiva } \\
\text { si } \\
\text { Ekster } \\
\text { nal }\end{array}$} & 1. & $\begin{array}{l}\text { Saya diberikan } \\
\text { kepercayaan } \\
\text { lembaga untuk } \\
\text { berkarya }\end{array}$ & 44 & 32 & 15 & 8 & 1 \\
\hline & 2. & $\begin{array}{l}\text { Saya } \\
\text { melakukan } \\
\text { tanggung } \\
\text { jawab karena } \\
\text { ada imbalan } \\
\text { yang pantas }\end{array}$ & 37 & 36 & 26 & 1 & $\mathbf{0}$ \\
\hline & 3. & $\begin{array}{l}\text { Saya } \\
\text { menjalankan } \\
\text { tugas sesuai } \\
\text { anjuran teman }\end{array}$ & 40 & 39 & 17 & 4 & 0 \\
\hline & 4. & $\begin{array}{l}\text { Saya mendapat } \\
\text { jaminan } \\
\text { keamanan } \\
\text { kerja di } \\
\text { lembaga ini }\end{array}$ & 51 & 32 & 16 & 1 & 0 \\
\hline & 5. & $\begin{array}{l}\text { Penghasilan } \\
\text { yang saya } \\
\text { terima saat ini } \\
\text { sudah sangat } \\
\text { memuaskan. }\end{array}$ & 24 & 39 & 26 & 9 & 2 \\
\hline & 6. & $\begin{array}{l}\text { Dengan } \\
\text { kekuasaan, } \\
\text { saya dapat } \\
\text { lebih } \\
\text { dihormati }\end{array}$ & 55 & 32 & 11 & 2 & 0 \\
\hline \multirow{6}{*}{$\begin{array}{c}\text { Motiva } \\
\text { si } \\
\text { Interna } \\
\text { l }\end{array}$} & 7. & $\begin{array}{l}\text { Saya } \\
\text { ndapatkan } \\
\text { keb } \\
\text { utuhan yang } \\
\text { layak }\end{array}$ & 38 & 35 & 21 & 5 & 1 \\
\hline & 8. & $\begin{array}{l}\text { Saya mer } \\
\text { asa } \\
\text { aman } \\
\text { am melakukan } \\
\text { pekerjaan }\end{array}$ & 29 & 45 & 19 & 5 & 2 \\
\hline & 9. & $\begin{array}{l}\text { Saya } \\
\text { memiliki } \\
\text { hubungan } \\
\text { yang erat } \\
\text { dengan semua } \\
\text { karyawan } \\
\end{array}$ & 31 & 44 & 15 & 10 & $\mathbf{0}$ \\
\hline & $\begin{array}{c}10 \\
.\end{array}$ & $\begin{array}{l}\text { Saya selalu } \\
\text { dan ingin } \\
\text { selalu } \\
\text { mendapat } \\
\text { penghargaan } \\
\text { atas pekerjaan } \\
\text { yang saya } \\
\text { lakukan. }\end{array}$ & 31 & 40 & 20 & 9 & 0 \\
\hline & $\begin{array}{c}11 \\
.\end{array}$ & $\begin{array}{l}\text { Saya suka } \\
\text { melaksanakan } \\
\text { tugas yang } \\
\text { menantang }\end{array}$ & 37 & 36 & 26 & 1 & $\mathbf{0}$ \\
\hline & $\begin{array}{c}12 \\
.\end{array}$ & $\begin{array}{l}\text { Sportivitas } \\
\text { dalam bekerja } \\
\text { merupakan } \\
\text { cita-cita saya }\end{array}$ & 40 & 39 & 17 & 4 & 0 \\
\hline \multicolumn{3}{|c|}{$\sum=1200$} & $\begin{array}{c}45 \\
7 \\
\end{array}$ & $\begin{array}{c}44 \\
9\end{array}$ & $\begin{array}{c}22 \\
9\end{array}$ & 59 & 6 \\
\hline
\end{tabular}




\begin{tabular}{|c|c|c|c|c|c|}
\hline$\sum=100 \%$ & $\mathbf{3 8}$, & $\mathbf{3 7}$, & $\mathbf{1 9}$, & $\mathbf{4 ,}$ & $\mathbf{0 ,}$ \\
& $\mathbf{1}$ & $\mathbf{4}$ & $\mathbf{1}$ & $\mathbf{9}$ & $\mathbf{5}$ \\
\hline
\end{tabular}

Sumber: data premier yang sudah diolah 2015

Pemberian motivasi yang maksimal yang telah dilakukan oleh karyawan pada Sekretariat Jendral Dewan Perwakilan Daerah Republik Indonesiamendapat respon yang baik, peneliti menyimpulkan demikian didasarkan pada hasil jawaban seluruh responden yang berjumlah 100 karyawan dengan jumlah pernyataan sebanyak 12 yang menjawab "sangat setuju" sebanyak 457 atau $38,1 \%$ atau sama dengan $\left(\frac{457}{1200}\right) * 100 \%$, kemudian disusul dengan jawaban "setuju" sebanyak 449 atau $37,4 \%$ atau $\left(\frac{449}{1200}\right) * 100 \%$, selebihnya yang menjawab "cukup setuju" sebanyak 229 atau $19,1 \%$ atau setara dengan $\left(\frac{229}{1200}\right) * 100 \%$, dan "kurang setuju" sebanyak 59 atau $4,9 \%$ sama dengan $\left(\frac{59}{1200}\right) * 100 \%$, sedangkan yang menjawab "tidak setuju" sebanya 6 , atau $0,5 \%$ atau $\left(\frac{6}{1200}\right) * 100 \%$.

Penilaian responden terhadap variabel motivasi terdapat 55 karyawan yang menjawab "sangat setuju" pada pernyataan ke 6 (Dengan kekuasaan, saya dapat lebih dihormati) hal ini mengindikasikan bahwa motivasi ekternal atau dari pihak luar menjadi salah satu indicator yang dapat mempengaruhi motivasi seorang karyawan sehingga dapat mempengaruhi kinerja dari karyawan tersebut dan 45 karyawan yang menjawab "setuju" pada pernyataan ke 8 (Saya merasaamandalammelakukan pekerjaan) hal ini menunjukan bahwa motivasi internal juga sangat mempengaruhi kinerja karyawan, jika pihak atasa jarang memberikan arahan atau masukan dapat mengakibatkan menurun nya motivasi kinerja seorang karyawan .

b. Penilaian Responden Terhadap Kompetensi

Tabel 13

Penilaian Responden Terhadap Kompetensi

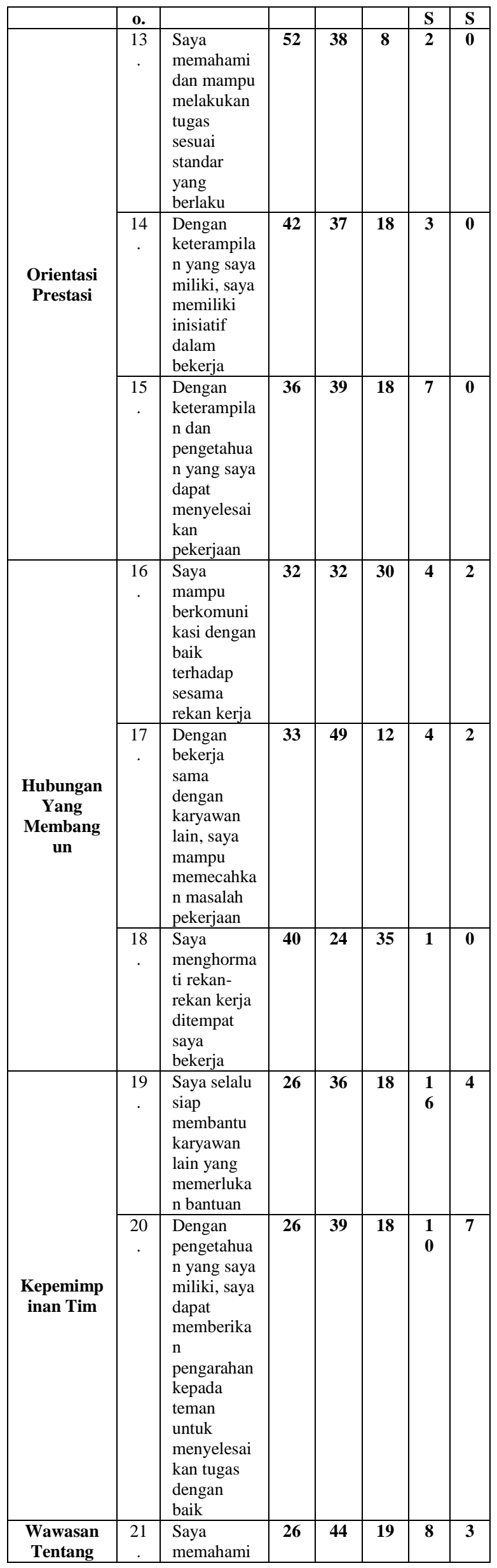




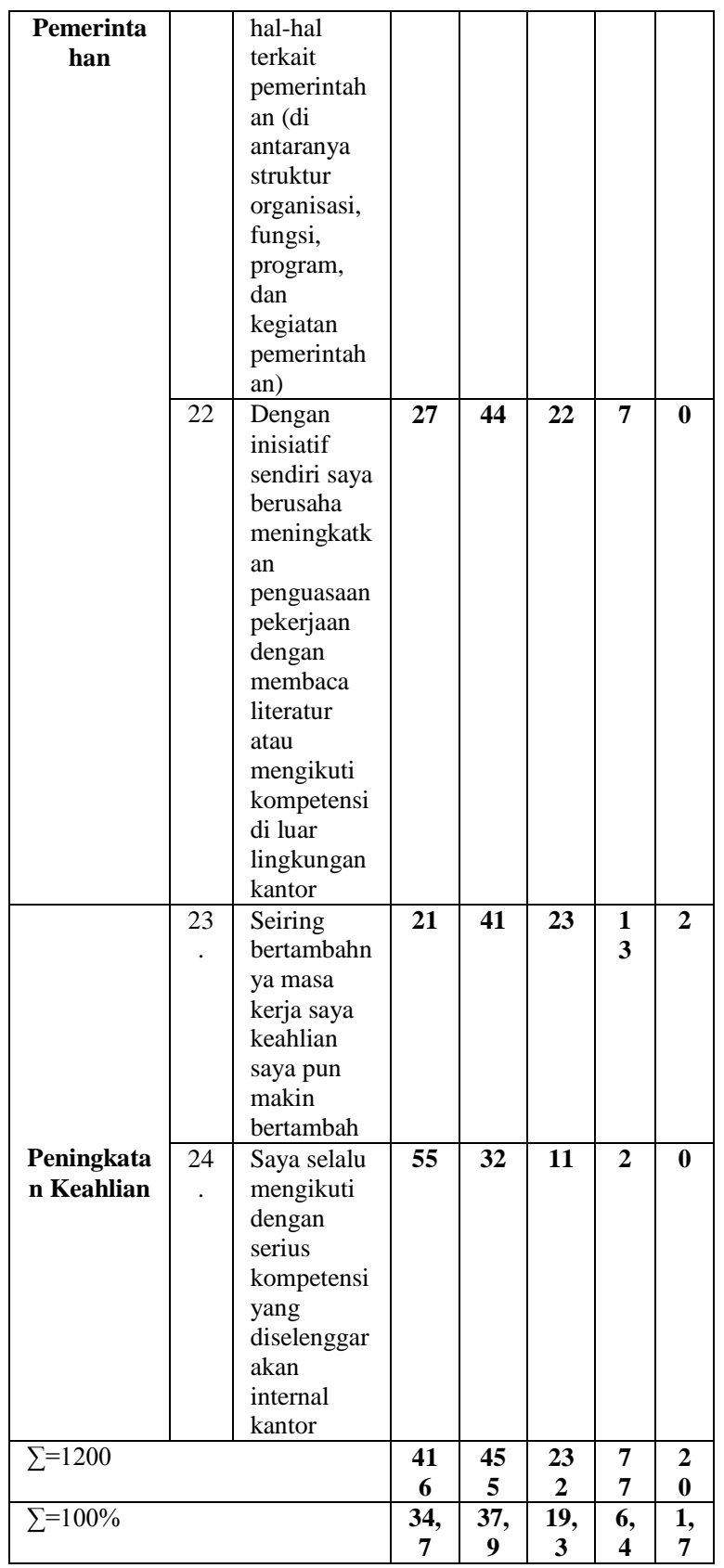

Sumber: data premier yang sudah diolah 2015

Penilaian terhadap komptensi pada karyawanSekretariat Jendral Dewan Perwakilan Daerah Republik Indonesiamendapat respon yang baik, peneliti menyimpulkan demikian didasarkan pada hasil jawaban seluruh responden yang berjumlah 100 orang dengan jumlah pernyataan sebanyak 12 yang menjawab "sangat setuju" sebanyak 416 atau $34,7 \%$ atau sama dengan $\left(\frac{416}{1200}\right) * 100 \%$, kemudian disusul dengan jawaban "setuju" sebanyak 455 atau $37,9 \%$ atau $\quad\left(\frac{455}{1200}\right) * 100 \%$, selebihnya yang menjawab "cukup setuju" sebanyak 232 atau $19,3 \%$ atau setara dengan $\left(\frac{232}{1200}\right) * 100 \%$, dan "kurang setuju" sebanyak 77 atau 6,4\% sama dengan $\left(\frac{77}{1200}\right) * 100 \%$, sedangkan yang menjawab "tidak setuju" sebanyak 20, atau $1,7 \%$ atau $\left(\frac{20}{1200}\right) * 100 \%$.

Penilaian responden terhadap variabel kompetensi terdapat 54 karyawan yang menjawab "sangat setuju" pada pernyataan ke 24 (Saya selalu mengikuti dengan serius kompetensi yang diselenggarakan internal inspektorat ) hal ini mengindikasikan bahwa meningkatkan keahlian terhadap karyawanSekretariat Jendral Dewan Perwakilan Daerah Republik Indonesiayang menjawab "setuju" pada pernyataan ke 17 (Dengan bekerja sama dengan karyawan lain, saya mampu memecahkan masalah pekerjaan) hal tersebut dapat membangunn hubungan terhadap karyawan sehingga berdampak pada kinerja karyawan tersebut

\section{c. Penilaian Responden Terhadap Kinerja}

\section{Tabel 14}

Penilaian Responden Terhadap Kinerja

\begin{tabular}{|c|c|c|c|c|c|c|c|}
\hline Dimensi & $\begin{array}{l}\mathbf{N} \\
\text { o. }\end{array}$ & Indikator & SS & $\mathbf{S}$ & $\mathrm{CS}$ & $\begin{array}{l}\mathbf{K} \\
\mathbf{S}\end{array}$ & $\begin{array}{l}T \\
\end{array}$ \\
\hline \multirow[t]{2}{*}{$\begin{array}{c}\text { Kualitas } \\
\text { Kerja }\end{array}$} & 25 & $\begin{array}{l}\text { Saya } \\
\text { mengerjaka } \\
\text { n suatu } \\
\text { pekerjaan } \\
\text { dengan } \\
\text { penuh } \\
\text { perhitunga } \\
\text { n }\end{array}$ & 57 & 24 & 9 & 9 & 1 \\
\hline & 26 & $\begin{array}{l}\text { Saya } \\
\text { mengerjaka } \\
\text { n suatu } \\
\text { pekerjaan } \\
\text { dengan } \\
\text { cekatan } \\
\end{array}$ & 49 & 28 & 13 & 9 & 1 \\
\hline \multirow[t]{2}{*}{$\underset{\text { Kerja }}{\text { Kuantitas }}$} & 27 & $\begin{array}{l}\text { Tingkat } \\
\text { pencapaian } \\
\text { volume } \\
\text { kerja yang } \\
\text { saya } \\
\text { hasilkan } \\
\text { telah } \\
\text { sesuai } \\
\text { dengan } \\
\text { harapan } \\
\text { lembaga }\end{array}$ & 56 & 28 & 9 & 4 & 3 \\
\hline & $\begin{array}{c}28 \\
. .\end{array}$ & $\begin{array}{l}\text { Lembaga } \\
\text { menetapka } \\
\mathrm{n} \text { target } \\
\text { kerja } \\
\text { dengan } \\
\end{array}$ & 54 & 29 & 12 & $\mathbf{0}$ & 5 \\
\hline
\end{tabular}




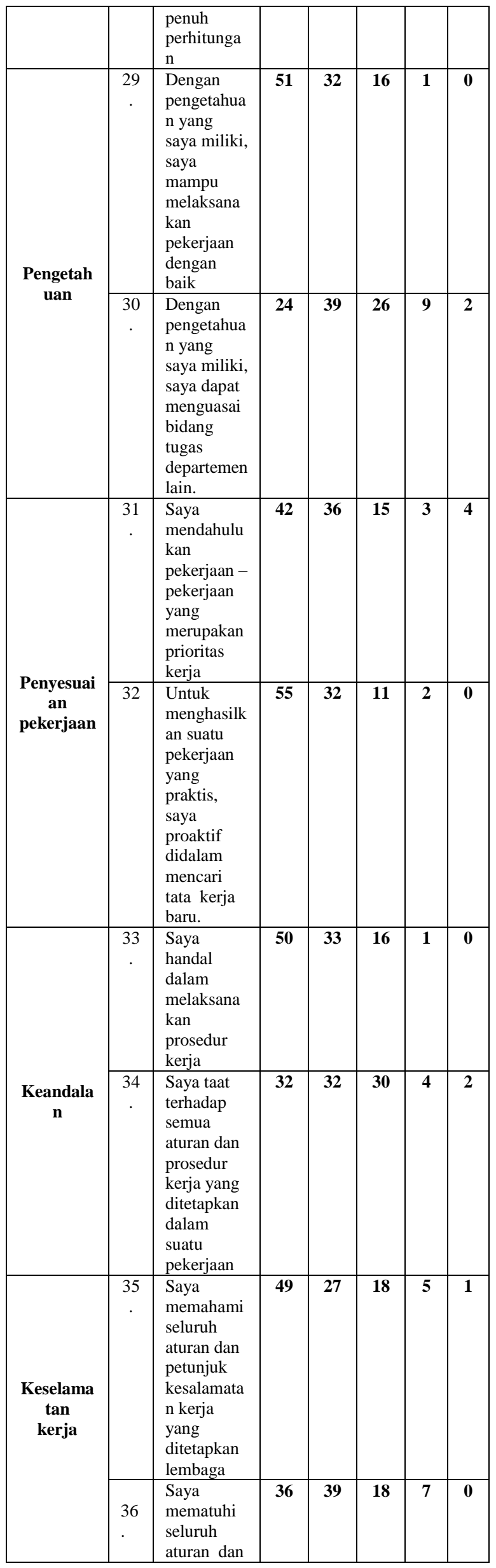

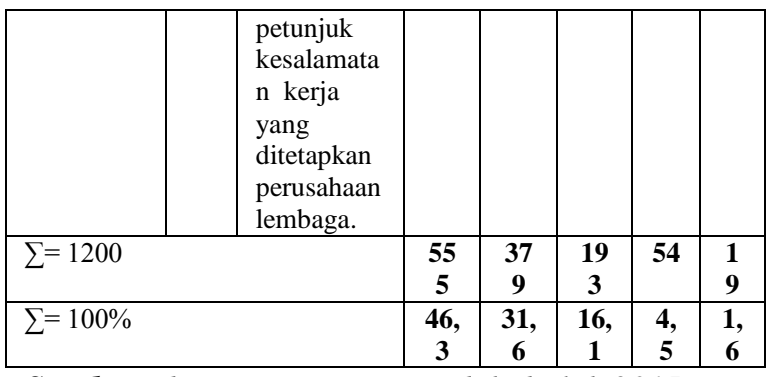

Sumber: data premier yang sudah diolah 2015

Berdasarkan hasil penilaian karyawan terhadap kinerja, maka diperoleh hasil yang maksimal terhadap kinerja yang telah dilakukan oleh karyawanSekretariat Jendral Dewan Perwakilan Daerah Republik Indonesiamendapat respon yang baik, peneliti menyimpulkan demikian didasarkan pada hasil jawaban seluruh responden yang berjumlah 100 orang dengan jumlah pernyataan sebanyak 12 yang menjawab "sangat setuju" sebanyak 555 atau 46,3\% atau sama dengan $\left(\frac{555}{1200}\right) * 100 \%$, kemudian disusul dengan jawaban "setuju" sebanyak 379 atau $31,6 \%$ atau $\quad\left(\frac{379}{1200}\right) * 100 \%$, selebihnya yang menjawab "cukup setuju" sebanyak 193 atau $16,1 \%$ atau setara dengan $\left(\frac{193}{1200}\right) * 100 \%$, dan "kurang setuju" sebanyak 54 atau $4,5 \%$ sama dengan $\left(\frac{54}{1200}\right) * 100 \%$, sedangkan yang menjawab "tidak setuju" sebanyak19, atau $1,6 \%$ atau $\left(\frac{19}{1200}\right) * 100 \%$.

Penilaian karyawan terhadap variabel kinerja terdapat 57 karyawan yang menjawab "sangat setuju" pada pernyataan ke 25 (Saya mengerjakan suatu pekerjaan dengan penuh perhitungan) hal ini mengindikasikan bahwa indicator kualitas kerja karyawan dapat mempengaruhi kinerja karyawan Sekretariat Jendral Dewan Perwakilan Daerah Republik Indonesiadan 49 karyawan yang menjawab "setuju" pada pernyataan ke 30 (Dengan pengetahuan yang saya miliki, saya dapat menguasai bidang tugas departemen lain) hal ini menandakan bahwa indicator dari pengetahuan terhadap karyawan sangat mempengaruhi kinerja karyawan dalam mengerjakan pekerjaanya dengan baik. 


\section{Analisis Verfikatif (Analisis Regresi Linear Berganda)}

Regresi berganda digunakan untuk mengetahui seberapa besar pengaruh variabel bebas ( motivasi dan komptensi) secara bersama-sama terhadap variabel terikat (kinerja), sehingga diketahui apakah variabel bebas tersebut berpengaruh positf atau negative terhadap kinerja karyawanSekretariat Jendral Dewan Perwakilan Daerah Republik Indonesia

Berdasarkan hasi dengan menggunakan software SPSS (Statistical Program For Social Science) version 17.00 for windows, maka diperoleh hasil sebagai berikut:

Tabel 15

Hasil Uji Regresi Berganda

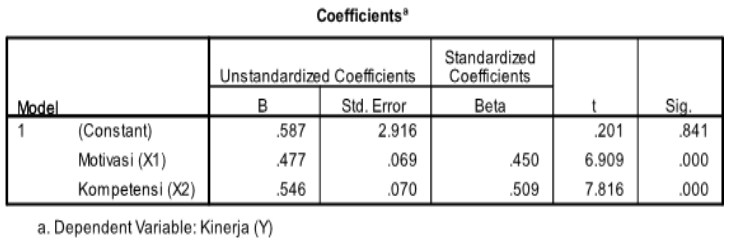

Sumber: data premier yang sudah diolah 2015

Dari data perhitungan diatas dapat disajikan kedalam bentuk persamaan regresi sebagaiberikut:

$Y=0,587+0,477 X_{1}+0,546 X_{2}$

Dimana:

Y merupakan Kinerja

$\mathrm{X}_{1}$ adalah Variabel Motivasi dan

$\mathrm{X}_{2}$ adalah Variabel Kompentensi

Hasil persamaan regresi berganda tersebut dapat dilihat bahwa koefiseinsi regresi yang diperoleh bertanda positif, hal ini menunjukan bahwa variabel Motivasi dan Kompetensi mempunyai pengaruh positif terhadap Kinerja Karyawan, yang artinya setiap ada peningkatan variabel Motivasi dan Kompetensi akan meningkatkan pula Kinerja karyawanSekretariat Jendral Dewan Perwakilan Daerah Republik Indonesia

Adapun persamaan tersebut dapat dijelaskan sebagai berikut:
1. Konstanta (a) sebesar 0,587, menyatakan bahwa tanpa variabel motivasi dan kompetensibesarnya nilai kinerja karyawan tetap terbentuk sebesar 0,587.

2. Variabel motivasi $\left(\mathrm{x}_{1}\right)$ berpengaruh positif terhadap kinerja karyawan (y) dengan nilai koefiseinsi sebesar 0,477. Yang artinya jika variabel motivasi $\left(\mathrm{x}_{1}\right)$ meningkat satu-satuan dengan asumsi varibel kompetensi $\left(\mathrm{x}_{2}\right)$ tetap, maka kinerja karyawan akan meningkat sebesar 0,477.

3. Variabel kompetensi $\left(\mathrm{x}_{2}\right)$ berpengaruh positif terhadap kinerja karyawan (y) dengan nilai koefiseinsi sebesar 0,546. Yang artinya jika variabel kompetensi $\left(\mathrm{x}_{2}\right)$ meningkat satu-satuan dengan asumsi varibel motivasi $\left(\mathrm{x}_{1}\right)$ tetap, maka kinerja karyawan akan meningkat sebesar 0,546.

\section{Uji Hipotesis}

\section{1.) Uji T (Parsial)}

Untuk menguji pengaruh variabel motivasi dan kompetensi secara parsial terhadap kinerja karyawanSekretariat Jendral Dewan Perwakilan Daerah Republik Indonesia, dapat digunakan dengan uji statistic t (uji t), dengan menggunakan taraf signifikansi $5 \%$ atau 0,05 dan drajat kebebasan (dk) dengan rumus:

$$
\mathbf{d k}=\mathbf{n}-\mathbf{k}-\mathbf{1}
$$

dimana $n$ adalah jumlah responden dan $k$ adalah jumlah variabel yang diteliti, kemudian dengan membandingkan $t_{\text {hitung }}$ dengan $t_{\text {tabel }}$ dengan kriteria:

$>$ Jika $\mathrm{t}$ hitung $\geq \mathrm{t}$ tabel, $(a ; d k)$, berarti $\mathrm{H}_{01}$ ditolak dan $\mathrm{H}_{\mathrm{a} 1}$ diterima.

$>$ Jika $\mathrm{t}$ hitung $\leq \mathrm{t}$ tabel, $(a ; d k)$, berarti $\mathrm{H}_{02}$ diterima dan $\mathrm{H}_{\mathrm{a} 2}$ ditolak 
Dimana drajat kebebasan ( $d k)$ adalah:

$$
\begin{aligned}
\mathrm{Dk} & =\mathrm{n}-\mathrm{k}-1 \\
& =100-2-1 \\
& =97 \\
\mathrm{t}_{\text {tabel }}= & \mathrm{t}(a ; d k) \\
& =(0,05 ; 97) \\
& =1,98
\end{aligned}
$$

Adapun hasil uji-t dengan pengolahan, SPSS (Statistical Product and Service Solutions) versi 17 for window, dapat dilihat pada tabel dibawah ini untuk masing-masing uji parsial:

\section{a.) Uji Hipotesis 1}

$\mathrm{H}_{01}$ : Diduga motivasitidak berpengaruh positif dan signifikan terhadap kinerja karyawanSekretariat Jendral Dewan Perwakilan Daerah Republik Indonesia

$$
\mathrm{H}_{\mathrm{a} 1} \text { : Diduga motivasi }
$$
berpengaruh positif dan signifikan terhadap kinerja karyawanSekretariat Jendral Dewan Perwakilan Daerah Republik Indonesia

Tabel 16 Hasil Uji Hipotesis 1

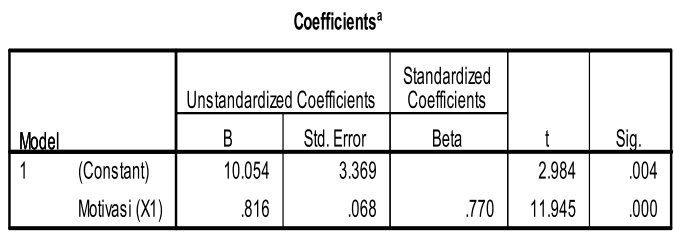

a. Dependent Variable: Kinerja (Y)

Sumber: data premier yang sudah diolah 2015

Berdasarkan perhitungan diatas dapat dilihat bahwa variabelmotivasi diperoleh $\mathrm{t}$ hitung11,945 dengan signifikansi $\mathrm{t}$ sebesar 0,000lebih besar dari $t_{\text {tabel }}$ sebesar 1,98 (11,945 $\geq 1,98)$ atau signifikansi t lebih kecil dari $0,05(0,000 \leq 0,05)$ berarti $\mathrm{H}_{01}$ ditolak dan $\mathrm{H}_{\mathrm{a} 1}$ diterimahal ini menunjukan bahwa variabel motivasi berpengaruh positif dan signifikan terhadap kinerja karyawanSekretariat Jendral Dewan Perwakilan Daerah Republik Indonesia

\section{b.) Uji Hipotesis 2}

$\mathrm{H}_{02}$ : Diduga kompetensi tidak berpengaruh positif dan signifikan terhadap kinerja

karyawanSekretariat

Jendral Dewan

Perwakilan Daerah

Republik Indonesia

$\mathrm{H}_{\mathrm{a} 2}$ : Diduga kompetensi berpengaruh positif dan signifikan terhadap kinerja karyawanSekretariat Jendral

\begin{tabular}{|c|c|c|c|c|c|c|}
\hline \multirow[b]{2}{*}{ Model } & & \multicolumn{2}{|c|}{ Unstandardized Coefficients } & \multirow{2}{*}{$\begin{array}{c}\begin{array}{c}\text { Standardized } \\
\text { Coefficients }\end{array} \\
\text { Beta }\end{array}$} & \multirow[b]{2}{*}{$t$} & \multirow[b]{2}{*}{ Sig. } \\
\hline & & B & Std. Error & & & \\
\hline 1 & (Constant) & 9.489 & 3.179 & & 2.985 & .004 \\
\hline & Kompetensi (X2) & .849 & .066 & .792 & 12.842 & .000 \\
\hline
\end{tabular}
Dewan Perwakilan Daerah Republik Indonesia

Tabel 17 Hasil Uji Hipotesis 2

Coefficients $^{\mathrm{a}}$

a. DependentVariable: Kinerja (M)

Sumber: data premier yang sudah diolah 2015

Dari table diatas dapat dilihat bahwa variabel kompetensi diperoleh $\mathrm{t}$ hitung 12,842 dengan signifikansi $\mathrm{t}$ sebesar 0,000 sehingga $t_{\text {hitunglebih besar dari } t}$ tabel sebesar 1,98 $(12,842 \geq 1,98)$ atau signifikansi $\mathrm{t}$ lebih kecil dari $0,05(0,000 \leq 0,05)$ berarti $\mathrm{H}_{02}$ ditolak dan $\mathrm{H}_{\mathrm{a} 2}$ diterimahal ini menunjukan bahwa variabel kompetensi berpengaruh positif dan signifikan terhadap kinerja karyawanSekretariat Jendral Dewan Perwakilan Daerah Republik Indonesia. 
2.) Uji F (Simultan)

Untuk menguji variabel motivasi dan kompetensi secara bersamasama terhadap kinerja karyawanSekretariat Jendral Dewan Perwakilan Daerah Republik Indonesia dapat digunakna uji statistic f, dengan menggunakan taraf signifikansi 5\% $(0,05)$ dan drajat kebebasan $(\mathrm{dk})$ dengan rumus: $d k=n-k-1$, Dimana $n$ adalah jumalah responden dan $k$ adalah jumah variabel yang diteliti, dan kemudian membandingkan dengan $\mathrm{F}$ hitung dengan $\mathrm{F}$ table dengan criteria sebagai berikut:

$>$ Jika $\mathrm{F}$ hitung $\geq \mathrm{F}$ tabel, $(a ; d k)$, berarti $\mathrm{H}_{01} ; \mathrm{H}_{02}$, ditolak dan $\mathrm{H}_{\mathrm{a} 1} ; \mathrm{H}_{\mathrm{a} 2}$ diterima.

$>$ Jika $\mathrm{F}_{\text {hitung }} \leq \mathrm{F}$ tabel, $(a ; d k)$, berarti $\mathrm{H}_{01} ; \mathrm{H}_{02}$ diterima dan $\mathrm{H}_{\mathrm{a} 1} ; \mathrm{H}_{02}$ ditolak

$\mathrm{F}_{\text {hitung }}$ dan $\mathrm{F}_{\text {tabel }}$

F hitungadalah 145,645 (lihat pada tabel anova)

F tabel dapat dicari pada tabel statistik pada signifikansi 0,05 :

df $1=\mathrm{k}-1$ atau $3-1=2$, dan

df $2=n-k$ atau $100-3=97(\mathrm{k}$ adalah jumlah variabel), di dapat $\mathrm{F}$ tabel adalah 3,09.

Adapun hasil uji-fdengan pengolahan, SPSS (Statistical Product and Service Solutions) versi 17 for window, dapat dilihat pada tabel dibawah:

Tabel 18

Hasil Uji F

ANOVA

\begin{tabular}{|c|c|c|c|c|c|c|}
\hline Mode & & $\begin{array}{l}\text { Sum of } \\
\text { Squares }\end{array}$ & $d f$ & Mean Square & $F$ & Sig. \\
\hline \multirow[t]{3}{*}{1} & Regression & 3312.005 & 2 & 1656.003 & 145.645 & $.000^{2}$ \\
\hline & Residual & 1102.905 & 97 & 11.370 & & \\
\hline & Total & 4414.910 & 99 & & & \\
\hline
\end{tabular}

a. Predictors: (Constant), Kompetensi (X2), Motivasi (X1)

b. Dependent Variable: Kinerja (Y)
Sumber: data premier yang sudah diolah, 2015

\section{Uji Hipotesis 3 dengan Uji Simultan (Uji F)}

$\mathrm{H}_{04}$ : Diduga motivasi dan kompetensi tidak berpengaruh positif dan

signifikan terhadap kinerja karyawanSekretariat

Jendral Dewan Perwakilan Daerah Republik Indonesia secara simultan.

$\mathrm{H}_{\mathrm{a} 4}$ : Diduga motivasi dan kompetensi berpengaruh positif dan signifikan terhadap kinerja karyawanSekretariat Jendral Dewan Perwakilan Daerah Republik Indonesia secara simultan.

Berdasarkan hasil uji anova pada tabel diatas dapat diperoleh $\mathrm{F}$ hitung 145,645 dengan signifikansi $F$ sebesar $0,000^{\mathrm{a}}$, sehingga $\mathrm{F}$ hitung lebih besar dari $\mathrm{F}$ tabel $=3,09$ $(145,645 \geq 3,09)$ atau signifikansi F lebih kecil dari $0,05(0,000 \leq$ $0,05)$, sesuai dengan kriteria yaitu: Jika $\quad \mathrm{F}$ hitung $\geq \mathrm{F}$ tabel $(\alpha ; d k)$ atau signifikansi $\mathrm{F} \leq 0,05$ berarti $\mathrm{H}_{04}$ ditolak dan $\mathrm{H}_{\mathrm{a} 4}$ diterima, hal ini menunjukan bahwa motivasi dan kompetensi berpengaruh positif dan signifikan terhadap kinerja karyawanSekretariat Jendral Dewan Perwakilan Daerah Republik Indonesia secara simultan.

\section{Koefisiensi Determinasi}

Untuk mengetahui besarnya kontribusi pengaruh variabel motivasi dan kompetensi secara parsial maupun simultan terhadap kinerja karyawanSekretariat Jendral Dewan Perwakilan Daerah Republik Indonesia, sebagai berikut:

1. Untuk mengetahui seberapa besar pengaruh terhadap motivasi terhadap kinerja karyawan 
karyawanSekretariat

Jendral

Dewan Perwakilan

Daerah

Republik Indonesia

Tabel 19

Hasil Uji Determinasi Variabel

Motivasi

Model Summary

\begin{tabular}{|c|c|r|r|r|}
\hline Model & $\mathrm{R}$ & $\mathrm{R}$ Square & $\begin{array}{c}\text { Adjusted } \mathrm{R} \\
\text { Square }\end{array}$ & $\begin{array}{c}\text { Std. Error of } \\
\text { the Estimate }\end{array}$ \\
\hline 1 & $.770^{\mathrm{a}}$ & .593 & .589 & 4.283 \\
\hline
\end{tabular}

a. Predictors: (Constant), Motivasi (X1)

b. Dependent Variable: Kinerja ( $Y$ )

Sumber: data premier yang sudah diolah 2015

Dari table diatas dapat dilihat bahwa nilai $\mathrm{R}$ Square sebesar 0,593 atau 59,3\%, hal ini menunjukan bahwa pengaruh motivasi terhadap kinerja karyawanSekretariat Jendral Dewan Perwakilan Daerah Republik Indonesia adalah 59,3\%.

2. Untuk mengetahui seberapa besar pengaruh kompetensi terhadap kinerja karyawan karyawanSekretariat Jendral Dewan Perwakilan Daerah Republik Indonesia

Tabel 20

Hasil Uji Determinasi Variabel Kompetensi

\begin{tabular}{|c|c|r|r|r|}
\multicolumn{9}{c|}{ Model Summary $^{\text {b }}$} \\
\hline Model & \multicolumn{1}{|c|}{ R } & R Square & $\begin{array}{c}\text { Adjusted R } \\
\text { Square }\end{array}$ & $\begin{array}{c}\text { Std. Error of } \\
\text { the Estimate }\end{array}$ \\
\hline 1 & $.792^{\mathrm{a}}$ & .627 & .623 & 4.098 \\
\hline
\end{tabular}

a. Predictors: (Constant), Kompetensi (X2)

b. Dependent Variable: Kinerja ( $Y$ )

Sumber: data premier yang sudah diolah 2015

Berdasarkan table diatas dapat dilihat bahwa nilai $\mathrm{R}$ square sebesar 0,627 atau $62,7 \%$. Hal ini menunjuka bahwa pengaruh kompetensi terhadap kinerja karyawanSekretariat Jendral Dewan Perwakilan Daerah Republik Indonesia sebesar $62,7 \%$
3. Untuk mengetahui seberapa besar pengaruh motivasi dan kompetensi terhadap kinerja karyawan karyawanSekretariat Jendral Dewan Perwakilan Daerah Republik Indonesia

Tabel 21

Hasil Uji Determinasi

Model Summary

\begin{tabular}{|c|c|r|r|r|}
\hline Model & $R$ & R Square & $\begin{array}{c}\text { Adjusted } R \\
\text { Square }\end{array}$ & $\begin{array}{c}\text { Std. Error of } \\
\text { the Estimate }\end{array}$ \\
\hline 1 & $.866^{\mathrm{a}}$ & .750 & .745 & 3.372 \\
\hline
\end{tabular}

a. Predictors: (Constant), Kompetensi (X2), Motivasi (X1)

b. Dependent Variable: Kinerja ( $M$

Sumber: data premier yang sudah diolah 2015

Dari table diatas dapat dilihat bahwa nilai $\mathrm{R}$ Square sebesar 0,750 , hal ini menunjukan bahwa motivasi dan kompetensi secara bersama-sama berpengaruh positif terhadap kinerja karyawanSekretariat Jendral Dewan Perwakilan Daerah Republik Indonesia sebesar $75 \%$

\section{Pembahasan}

Dari hasil pengujian hipotesis statistik dan analisis diatas, maka sesuai dengan maksud dan tujuan dalam penelitian ini dapat dipaparkan analisis pengaruh variabel bebas terhadap variabel terikat sebagai berikut:

Model regresi dalam penelitian ini adalah:

$$
Y=0,587+0,477 X_{1}+0,546 X_{2}
$$

1. Pengaruh Faktor Motivasi

Terhadap Kinerja Karyawan

Sekretariat Jendral Dewan

Perwakilan Daerah Republik Indonesia

a. Korelasi antara X1 dengan Y adalah 11,945

Adanya hubungan positif sebesar 11,945 antara faktor motivasi dan kinerja karyawanSekretariat Jendral 
Dewan Perwakilan Daerah Republik Indonesia.

b. $\mathrm{R}^{2}=0,593$

Data tersebut mengindikasikan bahwa faktor motivasi memberikan kontribusi postif sebesar 59,3 \% terhadap kinerja karyawanSekretariat Jendral Dewan Perwakilan Daerah Republik Indonesia.

2. Pengaruh Faktor Kompetensi Terhadap Kinerja karyawanSekretariat Jendral Dewan Perwakilan Daerah Republik Indonesia

a. Korelasi antara X2 dengan Y adalah 12,842

Adanya hubungan positif sebesar 12,842 antara faktor kompetensi dan kinerja karyawanSekretariat Jendral Dewan Perwakilan Daerah Republik Indonesia

b. $\mathrm{R}^{2}=0,627$

Data tersebut mengindikasikan bahwa faktor kompetensi memberikan kontribusi postif sebesar $62,7 \%$ terhadap kinerja karyawanSekretariat Jendral Dewan Perwakilan Daerah Republik Indonesia.

3. Model regresi ini memberikan kesimpulan bahwa, jika faktor $\left(\mathrm{x}_{1}\right)$ berpengaruh positif terhadap kinerja karyawan $(\mathrm{Y})$ dengan nilai koefisiensi sebesar 0,477. Yang artinya jika variabel motivasi $\left(\mathrm{x}_{1}\right)$ meningkat satu-satuan dengan asumsi varibel kompetensi $\left(\mathrm{x}_{2}\right)$ tetap, maka kinerja akan meningkat sebesar 0,477. Dan jika faktor kompetensi $\left(\mathrm{x}_{2}\right)$ berpengaruh positif terhadap kinerja karyawan (y) dengan nilai koefiseinsi sebesar 0,546 . Yang artinya jika variabel kompetensi $\left(\mathrm{x}_{2}\right)$ meningkat satusatuan dengan asumsi varibel motivasi $\left(\mathrm{x}_{1}\right)$ tetap, maka kinerja karyawan akan meningkat sebesar 0,546 . a. Besarnya nilai $\mathrm{R}$ square adalah 0,750

Data tersebut mengindikasikan bahwa factor recruitment dan kompetensi memberikan kontribusi yang positif sebesar $75 \%$ terhadap kinerja karywan dan selebihnya $25 \%$ diakibatkan oleh factor lainyang tidak diteliti oleh peneliti dapat berupa intensif pegawai, tingkat loyalitas kerja dan lainya.

b. Nilai $F$ hitung sebsar 145,645 dengan $\mathrm{p}_{\text {sig }} 0,000$ dan $\mathrm{F}$ table $=3.09$

Daerah kritis $\quad \mathrm{H}_{1} ; \quad \mathrm{H}_{2}=0$ "Ditolak" jika p.sig $<0.05$

Karena $\mathrm{F}_{\text {hitung }}>\mathrm{F}_{\text {tabel }}$ dan $\mathrm{p}_{\text {sig }}<$ 0,05, maka:

$\mathrm{H}_{1} ; \mathrm{H}_{2}=0$ "Ditolak" dan $\mathrm{H}_{1}$; $\mathrm{H}_{2} \neq 0$ "Diterima".

Hasil ini membuktikan bahwa terdapat pengaruh yang signifikan dari faktor Motivasi dan Kompetensi Terhadap Kinerja karyawanSekretariat Jendral Dewan Perwakilan Daerah Republik Indonesia.

Dari model-model regresi berganda ini juga diketahui bahwa "Kompetensi" Merupakan faktor yang paling dominan mempengaruhi "Kinerja Karyawan" Sekretariat Jendral Dewan Perwakilan Daerah Republik Indonesia.

\section{KESIMPULAN DAN SARAN}

\section{A. Kesimpulan}

Berdasarkan hasil analisi dan pembahasan pada bab IV diatas serta mengacu pada maksud dan tujuan penelitian, seperti yang telah dipaparkan pada bab sebelumnya, maka penelitian ini dapat ditarik kesimpulan:

1. Variabel motivasi $\left(\mathrm{x}_{1}\right)$ berpengaruh positif terhadap kinerja karyawan (y) 
dengan nilai koefiseinsi sebesar 0,477, yang artinya jika variabel motivasi (x1) meningkat satu-satuan dengan asumsi variabel kompetensi (x2) tetap maka kinerja karyawan akan meningkat sebesar 0,477 .

Dan sesuai dengan perumusan masalah bahwa besar nya pengaruh motivasi terhadap kinerja yaitu sebesar 59,3\%.

2. Variabel kompetensi (x2) berpengaruh positif dan terhadap kinerja karyawan (y) dengan nilai koefisiensi sebesar 0,546 yang artinya jika variabel kompetensi (x2) meningkat satusatuan dengan asumsi variabel motivasi tetap, maka kinerja karyawan akan meningkat sebesar 0,546.

Sesuai dengan perumusan masalah maka besarnya pengaruh kompetensi terhadap kinerja karyawan sebesar $62,7 \%$

Dari kedua variabel diatas dapat disimpulkan bahwa jika faktor $\mathrm{x}_{1}$ (motivasi) konstan, maka kenaikan satu-satuan pada $\mathrm{x}_{2}$ (kompetensi) dan akan meningkatkan satu-satuan pada y (kinerja karyawan) sebesar 0,477 dan jika faktor $\mathrm{x}_{2}$ (motivasi) konstan, maka kenaikan satu-satuan pada $\mathrm{x}_{1}$ (motivasi) akan meningkatkan y (kinerja) sebesar 0,546.

3. Faktor motivasi dan kompetensi bersama-sama mepunyai pengaruh yang positif dan signifikan terhadap kinerja karyawanSekretariat Jendral Dewan Perwakilan Daerah Republik Indonesia, dari tabel dapat dilihat bahwa R Square diperoleh sebesar 0,750 atau $75 \%$, hal ini dapat dijelaskan bahwa varibel motivasi dan kompetensi secara bersama-sama berpengaruh terhadap kinerja karyawanSekretariat Jendral Dewan Perwakilan Daerah Republik Indonesia dan sisanya $25 \%$ dipengaruhi oleh faktor lain yang tidak diteliti oleh peneliti seperti Intensif pegawai dan lain sebagainya. Dan sesuai dengan rumusan masalah maka besarnya pengaruh motivasi dan kompetensi terhadap kinerja secara simultan yiatu sebesar $75 \%$.

Model regresi berganda yang diperoleh : $\mathbf{Y}=\mathbf{0 , 5 8 7}+\mathbf{0 , 4 7 7} \mathbf{X}_{\mathbf{1}}+$ $0,546 \mathrm{X}_{2}$

Dari data-data tersebut didapat bahwa faktor kompetensi yang mempunyai kontribusi yang paling besar pengaruhnya terhadap kinerja karyawanSekretariat Jendral Dewan Perwakilan Daerah Republik Indonesia, jika faktor motivasi konstan, maka kenaikan sebesar satusatuan pada kompetensi menghasilkan kenaikan kinerja sebesar 0,546 satuan.

\section{B. Saran}

Berdasarkan kesimpulan yang telah dipaparkan diatas, berikut adalah saran yang dapat dilaksanakan oleh Sekretariat Jendral Dewan Perwakilan Daerah Republik Indonesia:

1. Sekretariat Jendral Dewan Perwakilan Daerah Republik Indonesia perlu meningkatkan motivasi tehadap karyawan misalnya dengan memberikan penghargaan kepada karyawan yang terbaik sehingga karyawan dapat bekerja dengan baik dan meningkatkan kinerja karyawan Sekretariat Jendral Dewan Perwakilan Daerah Republik Indonesia.

2. Sekretariat Jendral Dewan Perwakilan Daerah Republik Indonesia perlu meningkatkan kompetensi terhadap karyawan, baik karyawan baru maupun lama sehingga jika ada promosi jabatan mereka tidak perlu ragu untuk menjalani posisi barunya dan meningkatkan kinerja dari karyawan tersebut.

3. Sekretariat Jendral Dewan Perwakilan Daerah Republik Indonesia perlu meningkatkan kinerja pegawai dengan berbagai cara dapat dengan memberikan motivasi maupun memberikan intensi demi tercapai kinerja yang baik dan sesaui dengan 
yang diharapkan oleh Sekretariat Jendral Dewan Perwakilan Daerah Republik Indonesia.

\section{DAFTAR PUSTAKA}

A.A. Anwar Prabu Mangkunegara (2005), Manajamen Sumber Daya Manusia Perusahaan, PT Remaja Rosdakarya, Bandung.

As'ad, Moh (2005). Psikologi Indrustri. (Edisi IV). Yogyakarta. Liberty.

Gomes (2005). Organisasi dan Manajemen- Perilaku-StrukturProses, terjemahan Djoerban Wahid, Penerbit Erlangga, Jakarta.

Hasibuan, Malayu SP (2005), Manajemen dasar, Pengertian dan Masalah, C.V. Haji Masanggung, Jakarta.

Hasibuan, Malayu SP (2007), Manajemen Sumber Daya Manusia, Edisi Revisi, Penerbit Bumi Aksara, Jakarta.

Henry Simamora (2005), Manajemen Sumber Daya Manusia, STIE YKPN Bandung.

Taufik (2010), Strategi Belajar Mengajar,Inti Prima, Jakarta

Terry, George R, (2005). Personal Management, Edisi Ketujuh, Richard D Irwin, Inc., Homewood, Illinois., Bandung

Triton Prawira Budi (2006), SPSS 13.0 Terapan, Riset Statistik Parametrik, ANDI, Yogyakarta.

Winardi, (2005). Manajemen Supevisi, Penerbit Mandar Maju, Bandung
Sadili Samsudin (2005), Manajemen Sumber Daya Manusia, Pustaka Setia, Bandung.

Slameto (2010), Belajar Dan FaktorFaktor Yang Mempengaruhinya, Rineka Cipta, Jakarta

Soeratmo dan Arsyad Lincolin (2005), Metodologi Penelitian Untuk Ekonomi dan Bisnis, Edisi Revisi, UPP AMP YKPN, Universitas Gajah Mada, Yogyakarta.

Sugiyono (2007), Metode Penelitian Bisnis, Alfabeta, Bandung.

Suharsimi Arikunto (2005), Manajemen Penelitian, Edisi Revisi, Cetakan Ketujuh, Rineka Cipta, Jakarta.

Surakhmad Winarno (2005), Pengantar Penelitian Ilmiah, Tarsito, Bandung.

Susilo Martoyo (2005), Manajemen Sumber Daya Manusia, Edisi Kedua, BPFE, Yogyakarta. 